\title{
NMDA Receptors in Hippocampal GABAergic Synapses and Their Role in Nitric Oxide Signaling
}

\author{
Eszter Szabadits, ${ }^{1}$ Csaba Cserép, ${ }^{1}$ András Szőnyi, ${ }^{1}$ Yugo Fukazawa, ${ }^{2}$ Ryuichi Shigemoto, ${ }^{2}$ Masahiko Watanabe,${ }^{3}$ \\ Shigeyoshi Itohara, ${ }^{4}$ Tamás F. Freund, ${ }^{1}$ and Gábor Nyiri ${ }^{1}$ \\ ${ }^{1}$ Laboratory of Cerebral Cortex Research, Institute of Experimental Medicine, Hungarian Academy of Sciences, H-1083, Budapest, Hungary, ${ }^{2}$ Division of \\ Cerebral Structure, National Institute for Physiological Sciences, Okazaki 444-8787, Japan, ${ }^{3}$ Department of Anatomy, Hokkaido University School of \\ Medicine, Sapporo 060-8638, Japan, and ${ }^{4}$ Laboratory for Behavioral Genetics, Brain Science Institute, RIKEN, Saitama 351-0198, Japan
}

GABAergic inhibition plays a central role in the control of pyramidal cell ensemble activities; thus, any signaling mechanism that regulates inhibition is able to fine-tune network patterns. Here, we provide evidence that the retrograde nitric oxide (NO)-cGMP cascade triggered by NMDA receptor (NMDAR) activation plays a role in the control of hippocampal GABAergic transmission in mice. GABAergic synapses express neuronal nitric oxide synthase (nNOS) postsynaptically and NO receptors (NO-sensitive guanylyl cyclase) in the presynaptic terminals. We hypothesized that-similar to glutamatergic synapses-the $\mathrm{Ca}^{2+}$ transients required to activate nNOS were provided by NMDA receptor activation. Indeed, administration of $5 \mu \mathrm{M}$ NMDA induced a robust nNOS-dependent cGMP production in GABAergic terminals, selectively in the CA1 and CA3c areas. Furthermore, using preembedding, postembedding, and SDS-digested freeze-fracture replica immunogold labeling, we provided quantitative immunocytochemical evidence that NMDAR subunits GluN1, GluN2A, and GluN2B were present in most somatic GABAergic synapses postsynaptically. These data indicate that NMDARs can modulate hippocampal GABAergic inhibition via NO-cGMP signaling in an activity-dependent manner and that this effect is subregion specific in the mouse hippocampus.

\section{Introduction}

Nitric oxide (NO) is known to be able to change synaptic strength and influence long-term plasticity at hippocampal excitatory synapses (Prast and Philippu, 2001; Domek-Łopacińska and Strosznajder, 2005; Zhang et al., 2006; Edwards and Rickard, 2007). In pyramidal cells, NO is generated postsynaptically by neuronal nitric oxide synthase (nNOS) from L-arginine (Alderton et al., 2001; Burette et al., 2002; Stuehr et al., 2004), in low nanomolar concentrations under physiological conditions, and its receptor, the $\mathrm{NO}$-sensitive guanylyl cyclase (NOsGC), can detect even a few NO molecules. The NO signal is detectable only within approximately a micrometer around its site of synthesis; thus, it is not only effective but also synapse specific (for review, see Garthwaite, 2008). Activation of NOsGC leads to cGMP pro-

Received Nov. 11, 2010; revised Feb. 11, 2011; accepted Feb. 11, 2011.

Author contributions: E.S., T.F.F., and G.N. designed research; E.S., C.C., A.S., and G.N. performed research; Y.F., R.S., M.W., and S.I. contributed unpublished reagents/analytic tools; E.S. and G.N. analyzed data; E.S., T.F.F., and G.N. wrote the paper.

This work was supported by the Howard Hughes Medical Institute Grant 55005608; European Union Grants LSHM-CT-2004-005166 and LSHM-CT-2006-037315; Nemzeti Kutatási és Technológiai Hivatal-Országos Tudományos Kutatási Alapprogramok Grant CNK77793; and National Institutes of Health Grants DA09158, MH054671, and NS030549. G.N. was supported by János Bolyai Research Fellowship. E.S. and G.N. were supported by Japan Society for the Promotion of Science. We thank Prof. Jan de Vente for the CGMP antibody and Dr. N. Hájos and B. Németh for their help with slice preparations. We thank Drs. Takuji Iwasato and Reiko Ando for their help with the pyramidal cell-restricted GluN1 knock-out mice. The technical assistance of K. Lengyel, K. Iványi, and G. Goda is also acknowledged.

The authors declare no competing financial interests.

Correspondence should be addressed to Gábor Nyiri, Institute of Experimental Medicine, Hungarian Academy of Sciences, Szigony utca 43, H-1083, Budapest, Hungary. E-mail: nyiri@koki.hu.

DOI:10.1523/JNEUROSCI.5938-10.2011

Copyright $\odot 2011$ the authors $\quad 0270-6474 / 11 / 315893-12 \$ 15.00 / 0$ duction, which modulates neurotransmitter release through different second messenger systems. nNOS is a $\mathrm{Ca}^{2+} /$ calmodulindependent enzyme (Bredt and Snyder, 1990); thus, it is coupled to postsynaptic density proteins via postsynaptic density-95/ Discs large/zona occludens-1 (PDZ) domains that anchor nNOS close to NMDA receptors (NMDARs) in glutamatergic synapses (Kornau et al., 1995; Brenman and Bredt, 1997; Tochio et al., 2000). Local calcium influx through NMDARs can trigger the production of NO, which induces cGMP production in the hippocampus (East and Garthwaite, 1991).

Retrograde signaling can effectively control presynaptic plasticity at inhibitory connections (McBain and Kauer, 2009). In a previous study, we showed that the molecular machinery for NO signaling is present also in hippocampal GABAergic synapses and, similar to excitatory synapses, nNOS is localized postsynaptically within the active zone (Szabadits et al., 2007). However, the source of a local, sufficiently high $\mathrm{Ca}^{2+}$ influx that could lead to nNOS activation in GABAergic synapses is still unknown. Therefore, we investigated whether NMDARs can be found in association with GABAergic synapses. NMDAR-mediated currents generated in cell bodies have already been recorded from hippocampal pyramidal cells, and were considered to be mediated by extrasynaptic NMDARs (Gibb and Colquhoun, 1991; Steigerwald et al., 2000; Harris and Pettit, 2007), because there are no excitatory synapses on these somata (Megías et al., 2001). NMDARs are heterotetramers of two obligatory GluN1 (former NR1) and two GluN2 (NR2) subunits (Monyer et al., 1992; Laube et al., 1998). Pyramidal cells in the adult hippocampus express only GluN1, 2A, and 2B subunits (Watanabe et al., 1993; Ito et al., 
1997). We tested whether activation of local NMDARs can lead to the generation of cGMP in GABAergic terminals and examined the location of these NMDA receptors relative to GABAergic synapses.

We show that NMDA administration leads to cGMP production in GABAergic terminals in the hippocampal CA1 subfield, exclusively via activation of $\mathrm{nNOS}$. We also found that NMDAR subunits GluN1, GluN2A, as well as GluN2B are located in most somatic GABAergic synapses postsynaptically, in both types of basket cell synapses, although at a lower density than in excitatory synapses.

\section{Materials and Methods}

Animals. All experiments were performed in accordance with the Institutional Ethical Codex and the Hungarian Act of Animal Care and Experimentation guidelines, which are in concert with the European Communities Council Directive of November 24, 1986 (86/609/EEC). Young adult male C57BL/6 mice between the ages of 30 and $60 \mathrm{~d}$ were used in all experiments. Mice lacking nNOS $\left(\mathrm{nNOS}^{-1-}\right)$ were generated by The Jackson Laboratory. The pyramidal cell-restricted GluN1 knockout mice that lack GluN1 subunit only in cortical excitatory neurons have been characterized previously (Iwasato et al., 2000).

Antibodies and drugs. The specificity of the cGMP and the GAD65 antibodies were tested extensively and were described previously (de Vente et al., 1987; Chang and Gottlieb, 1988; Tanaka et al., 1997). GABA receptor $\left(\mathrm{GABA}_{\mathrm{A}} \mathrm{R}\right) \beta 3$ subunit antibodies also specifically labeled GABAergic synapses on pyramidal cell somata (Kasugai et al., 2010). nNOS and vesicular glutamate transporter 3 (vGluT3) antibodies were proved to be also specific in experiments with wild-type and nNOS ${ }^{-1-}$ and vGluT3 ${ }^{-1-}$ null mutant mice (data not shown). The specificity of the rabbit antibodies against the $\mathrm{C}$ terminus of the NMDAR subunits GluN1, GluN2A, and GluN2B had been well characterized by using immunoblot, antigen peptides, and null mutant mice or conditioned knock-out mice in both preembedding and postembedding experiments (Watanabe et al., 1998; Fukaya et al., 2003; Abe et al., 2004; Akashi et al., 2009). We used the same preembedding digestion protocol, as was used in the experiments for testing the specificity of the antibodies (Watanabe et al., 1998). We also performed additional control experiments to validate the specificity of the antibodies used in our experiments. We labeled freeze-fracture replicas of hippocampal slices of pyramidal cell-restricted GluN1 knock-out mice and wild-type mice to test specificity of the GluN1 antibody even further on replicas. We found no synaptic labeling and only negligible background labeling on pyramidal cell somata (for more details, see Results). In addition, GluN1, GluN2A, and GluN2B immunogold labeling displayed the same distribution in the tissue, using three different methods. Furthermore, in postembedding immunolabeling experiments, we performed mirror experiments as well: adjacent sections of the same synapses were incubated for GluN1, GluN2A, or GluN2B, respectively. If a synapse was labeled for any of the subunits, the very same synapse was also tested for other subunit labeling on adjacent sections. Although it is highly unlikely that the same channel could be tested in adjacent sections, using this method, the different subunits of the NMDARs could be colocalized in the same synapse. Indeed, we found that in the majority of the GluN2-positive synapses GluN1 was also detected in one of the adjacent sections (12 of 23 synapses in two mice) (see Fig. $3 D, E$ ), which demonstrates that these antibodies label the very same cell membrane domains, proving additional evidence for their specificity.

We also tested the cross-reactivity of the fluorescent secondary and gold-conjugated secondary antibodies used in double-labeling experiments. No cross-reactivity was found in either case. Selective labeling, resembling that obtained with the specific antibodies, could not be detected if primary antibodies were omitted.

3-Isobutyl-1-methylxanthine (IBMX), 1-(2-chlorophenyl)-6-[(2R)3,3,3-trifluoro-2-methylpropyl]-1,5-dihydro-4 $H$-pyrazolo[3,4-d]pyrimidine-4-one (BAY 73-6691), L-arginine, $\mathrm{L}-N^{\mathrm{G}}$-nitroarginine methyl ester hydrochloride (L-NAME), and (5R,10S)-(+)-5-methyl-10,11-dihydro- $5 H$ dibenzo $[a, d]$ cyclohepten-5,10-imine-hydrogen-maleate (MK-801) were produced by Sigma-Aldrich. NMDA, D-(-)-2-amino-5-phosphonopentanoic acid (D-AP5), $1 H$-[1,2,4] oxadiazolo[4,3-a]quinoxalin-1-one
(ODQ), nifedipine, and SNX-482 were obtained from Tocris Bioscience. We obtained tetrodotoxin (TTX) from Alomone Labs and sodium nitroprusside (SNP) from Fluka.

Acute slice preparation and cGMP immunolabeling. For acute slice preparation, mice were deeply anesthetized with isoflurane $(n=10$ C57BL/6; $n=4 \mathrm{nNOS}^{-1-}$ ) and decapitated, the brains were removed, and $300-\mu \mathrm{m}$-thick coronal hippocampal slices were cut on vibratome (Leica; VT1200S). Slices were incubated for $1 \mathrm{~h}$ in artificial CSF (ACSF) (in mM: $126 \mathrm{NaCl}, 2.5 \mathrm{KCl}, 1.25 \mathrm{NaH}_{2} \mathrm{PO}_{4}, 2 \mathrm{MgCl}_{2}, 2 \mathrm{CaCl}_{2}, 26$ $\mathrm{NaHCO}_{3}$, and 10 glucose) equilibrated with $95 \% \mathrm{O}_{2} / 5 \% \mathrm{CO}_{2}$ (carbogen gas), at room temperature in interface conditions before the experiments. Slices were then transferred to sterile 12-well cell culture plates (TPP) and were individually bubbled with carbogen gas at equal rates. Each well was filled with $1 \mathrm{ml}$ of modified ACSF (mACSF) containing 1 mM IBMX and $100 \mu \mathrm{M}$ BAY 73-6691 phosphodiesterase inhibitors (PDEInhs) (to avoid cGMP hydrolysis) and $0.2 \mathrm{mM} \mathrm{L}$-arginine (the substrate of nNOS). L-Arginine ( $0.2 \mathrm{~mm}$ ) alone has no effect on nNOS activity and cGMP levels (Garthwaite et al., 1989). After preincubation in mACSF for $20 \mathrm{~min}$, no drugs were applied in the control wells, whereas $200 \mu \mathrm{M}$ SNP was added for $10 \mathrm{~min}$ to "SNP wells" and $5 \mu \mathrm{M}$ NMDA was applied for 3 min to the "NMDA wells." The same region-specific cGMP labeling was observed with the application of 5, 30, 150, and $300 \mu \mathrm{M}$ NMDA. In experiments in which nNOS, NOsGC, voltage-dependent $\mathrm{Ca}^{2+}$ channels (VDCCs), or NMDARs were blocked, slices were preincubated for 20 min with $\mathrm{mACSF}$ containing the given blocker, and then $5 \mu \mathrm{M}$ NMDA was applied for $3 \mathrm{~min}$. After incubation, the solutions were quickly changed to ice-cold $4 \%$ paraformaldehyde fixative, and then the slices were postfixed in the same fixative for $48 \mathrm{~h}$ at $4^{\circ} \mathrm{C}$. These experiments were performed in normal mACSF solution as described above. However, to test the contribution of spontaneous action potentials in the slices, these experiments were repeated also with another mACSF solution containing $1 \mu \mathrm{M}$ TTX, without $\mathrm{Mg}^{2+}$. Both of these experimental conditions provided identical results, with indistinguishable staining pattern. In addition, we also tested the effect of NMDA in slices with TTX with normal $\mathrm{Mg}^{2+}$ concentration; however, as expected, under these conditions the activity of the network was too low to occasionally remove the $\mathrm{Mg}^{2+}$ block of these receptors for NMDA to be able to activate them.

For the immunofluorescent staining, the slices were washed in $0.1 \mathrm{M}$ phosphate buffer (PB), embedded in $2 \%$ agar, and resectioned into 50 $\mu \mathrm{m}$-thick sections on a vibratome (Leica; VT1200S). After washes in PBS containing $0.3 \%$ Triton X-100 (PBST) (Sigma-Aldrich), sections were blocked for $1 \mathrm{~h}$ in 5\% normal donkey serum (Vector Laboratories) dissolved in PBST. Then sections were incubated in primary antibody solutions: sheep anti-cGMP (from J. de Vente, Maastricht, The Netherlands; 1:4000) and mouse anti-GAD65 (only in colocalization experiments; Millipore; MAB351; 1:250) diluted in PBS. This was followed by washes in PBS and incubation in biotinylated donkey anti-mouse antibodies (only in colocalization experiments; 1:200; Jackson ImmunoResearch Laboratories) diluted in PBS. After subsequent washes in PBS, sections were incubated in a mixture of secondary antibodies: Alexa Fluor 488 donkey anti-sheep (1:200; Invitrogen) and Alexa Fluor 594 streptavidin (1:200; Invitrogen) diluted in PBS. This was followed by washes in PBS and $\mathrm{PB}$, and sections were mounted onto glass slides, coverslipped with Aqua-Poly/Mount (Polysciences). Immunofluorescence was analyzed using an Olympus Optical FluoView300 confocal laser-scanning (see Fig. $1 \mathrm{~K}$ ) or Zeiss Axioplan 2 epifluorescent microscope (see Fig. $1 \mathrm{~A}-J$ ). For comparing the fluorescent signals, sections were compared using constant parameters and exposure times. We show the differences in the staining pattern of differentially treated hippocampi on Figure 1. Exposure conditions for the first column of Figure $1 A-I$ (low-power images) were identical and exposure conditions for all other photos of Figure 1, $A-I$ and $J$ (highpower images), were identical as well. Therefore, these figures represent the differences between different staining patterns on Figure $1 A-J$.

Lowicryl resin embedding and postembedding immunohistochemistry. The same embedding procedure was used as described previously (Baude et al., 1993; Nyíri et al., 2001, 2003). Briefly, after washing in PB, the sections from fixed hippocampi were transferred into sucrose solutions in $0.1 \mathrm{M}$ PB for cryoprotection. After slamming onto gold-plated copper blocks cooled in liquid nitrogen, low temperature dehydration, and 
freeze-substitution, the sections were embedded in Lowicryl HM 20 resin (Chemische Werke Lowi).

Postembedding immunohistochemistry was performed on 50- or 70nm-thick sections of Lowicryl-embedded hippocampi from two mice. The sections were picked up either on pioloform-coated single slot nickel grids, allowing immunoreaction on one side of the sections (single-sided reactions), or on mesh grids, where both sides of the sections were labeled at the same time (double-sided reactions). Single-sided reactions were used to further test antibody specificity by colocalizing the NMDAR subunits in the same synapse using the mirror technique.

In double-sided reactions, the level of the immunogold signal is much higher but the reconstruction of terminals is not feasible. In these reactions, mesh grids were etched with a saturated solution of Na-ethanolate for 2-3 s and washed in distilled water. Then all grids were incubated on drops of blocking solution for $1 \mathrm{~h}$, followed by incubation on drops of primary antibodies overnight. The blocking solution, which was also used for diluting the primary and secondary antibodies, contained $2 \%$ human serum albumin (HSA) (Sigma-Aldrich) in Tris-buffered saline (TBS). After incubation in primary antibodies against NMDAR subunits (rabbit; $24 \mu \mathrm{g} / \mathrm{ml}$ GluN1, $20 \mu \mathrm{g} / \mathrm{ml}$ GluN2A, $18 \mu \mathrm{g} / \mathrm{ml}$ GluN2B; raised in the laboratory of $\mathrm{M}$. Watanabe) for $18 \mathrm{~h}$, sections were washed in TBS and incubated for $5 \mathrm{~h}$ on drops of secondary antibodies coupled to $5 \mathrm{~nm}$ gold particles (1:100; goat anti-rabbit; British Biocell International). In case of the mirror experiments, ultra-small gold secondary antibodies were used (1:100; donkey anti-rabbit; Aurion), and then gold particles were intensified using silver enhancement solution (SE-EM; Aurion) for $40 \mathrm{~min}$ at room temperature. After several washes, sections were finally rinsed in ultrapure water and contrasted with saturated aqueous uranyl acetate and lead citrate.

In double-sided reactions, immunoparticles for NMDAR subunits were counted within the anatomically defined GABAergic or glutamatergic synaptic junctions and along the somatic membrane. Forty-fivenanometer-wide bands were chosen on the two sides of the synaptic membrane as an area representing membrane-associated gold particle labeling. The reason for this is that the length of the $\mathrm{C}$ terminus of the NMDARs is $\sim 10 \mathrm{~nm}$, the primary and secondary IgG antibody molecules are $\sim 10-15 \mathrm{~nm}$ in length each, and the width of gold particle is 5 $\mathrm{nm}$. According to our experience, gold particles may also move a few nanometers on the surface of the section after immunocytochemistry, which can also cause a few nanometers shift in receptor labeling. However, this distribution was also tested (see Fig. 2C), and we found that actually the majority of all gold particles were within two 20 -nm-wide bands from the postsynaptic membrane (median, $3.63 \mathrm{~nm}$; interquartile range, $0-12.8$ ).

SDS-digested freeze-fracture replica immunolabeling. Mice $(n=3$ C57BL/6 mice; $n=2$ pyramidal cell-restricted GluN1 knock-out mice) were deeply anesthetized with sodium pentobarbital (50 mg/kg, i.p.), followed by transcardial perfusion first with $25 \mathrm{~mm}$ PBS for $1 \mathrm{~min}$, and then with $2 \%$ paraformaldehyde with $15 \%$ saturated picric acid in $0.1 \mathrm{M}$ PB for $12 \mathrm{~min}$. Coronal sections from the hippocampus were cut on a Dosaka microslicer at a thickness of $130 \mu \mathrm{m}$. The slices were cryoprotected in $30 \%$ glycerol in $0.1 \mathrm{M} \mathrm{PB}$ overnight at $4^{\circ} \mathrm{C}$ and were frozen by a high-pressure freezing machine (HPM 100; BAL-TEC). Frozen samples were inserted into a double replica table and then fractured into two pieces at $-140^{\circ} \mathrm{C}$. Fractured faces were replicated by deposition of carbon ( $8 \mathrm{~nm}$ thickness), platinum $(2 \mathrm{~nm})$, and carbon $(15 \mathrm{~nm})$ in a freezefracture replica machine (BAF 060; BAL-TEC). Samples were treated with $15 \mathrm{~mm}$ Tris buffer, $\mathrm{pH} 8.3$, containing 2.5\% SDS and 20\% sucrose at $80^{\circ} \mathrm{C}$ for $20 \mathrm{~h}$. The replicas were washed in $25 \mathrm{~mm}$ TBS containing $0.05 \%$ bovine serum albumin (BSA) (Nacalai Tesque) and then incubated in blocking solution (5\% BSA in $25 \mathrm{~mm}$ TBS) for $1 \mathrm{~h}$. The replicas were then incubated first in one of the primary antibody solutions recognizing NMDAR subunits (rabbit; $6 \mu \mathrm{g} / \mathrm{ml}$ GluN1, $10 \mu \mathrm{g} / \mathrm{ml}$ GluN2A, $8 \mu \mathrm{g} / \mathrm{ml}$ GluN2B in blocking solution), overnight at room temperature. After washing in TBS, replicas were incubated in the mixture of the $\mathrm{GABA}_{\mathrm{A}} \mathrm{R}$ $\beta 3$ subunit primary antibody (1:25; serum, guinea pig, raised and characterized in the laboratory of R. Shigemoto) (Kasugai et al., 2010) and gold-conjugated anti-rabbit secondary antibodies for NMDARs (1:25; BBI; $5 \mathrm{~nm}$ goat anti-rabbit) overnight at room temperature. This was followed by the gold-conjugated secondary antibodies to label $\mathrm{GABA}_{\mathrm{A}} \mathrm{Rs}$
(1:25; BBI; $10 \mathrm{~nm}$ goat anti-guinea pig). After washing in TBS and distilled water, replicas were picked up onto pioloform-coated parallel copper grids and were examined using Philips Tecnai 10 or Hitachi H-7100 transmission electron microscopes.

Delineation of GABAergic synapses on the surface of pyramidal cell somata on replica samples. One of the advantages of replica labeling is that a synapse does not need to be reconstructed from many of its sections, but the whole synapse is immediately visible over the surface of the somatic membrane (see Figs. 4, 5). Frequently, sections fracture along the membrane of the somata, exposing intramembrane proteins. Clusters of $\mathrm{GABA}_{\mathrm{A}} \mathrm{R}$ labeling are characteristic of GABAergic synapses (see Figs. $4 \mathrm{~A}$, 5). In classical immunohistochemistry methods, the tissue is embedded in resin and synapses are identified most often when cut perpendicular to the plane of the synaptic cleft (see Figs. 3, 6). Consequently, presynaptic and postsynaptic structures are readily visible, and delineation of the synaptic specialization is well defined. However, synapses on replicas are different. On the surface of freeze-fracture replicas, intramembrane particles (IMPs) (which can be observed on the surface of the cells) have a somewhat higher density in putative GABAergic synapses compared with the extrasynaptic surfaces. However, because not all IMP clusters define GABAergic synapses, we exclusively used the local density of $G_{A B A} R$ labeling to delineate GABAergic synapse-associated area in this study.

Briefly, after the replica samples were double-labeled with immunogold particles, large areas of the pyramidal cell surfaces $\left(\sim 60 \mu \mathrm{m}^{2}\right.$ area from each neuron) were reconstructed at high magnification using several (100-200) electron-microscopic photos. Using Adobe Photoshop CS4 Extended, a radial grayscale gradient was placed around every $\mathrm{GABA}_{\mathrm{A}} \mathrm{R}$ immunogold particle (this gradient looked like a disk). The exact position of $\mathrm{GABA}_{\mathrm{A}} \mathrm{R}$ immunogold particle was in the center of this gradient disk. These gradients extended $200 \mathrm{~nm}$ from the edge of the 10 $\mathrm{nm}$ gold particles. The gray values of the gradients were maximal over the gold particles and they were zero $200 \mathrm{~nm}$ away (at the edge of the disks). The decrease of the grayscale value was linear. Because these grayscale gradients were placed over all gold particles (which labeled $\mathrm{GABA}_{\mathrm{A}} \mathrm{R}$ s), most of them overlapped with each other (especially in synapses). Overlapping grayscale values were summed at each pixel of the photo of the somatic surface, which created a new grayscale map as a function of the local density of $\mathrm{GABA}_{\mathrm{A}} \mathrm{R}$ labeling (see Fig. $4 \mathrm{~B}$ ) (for better demonstration, continuous grayscales values are converted to grayscale steps). These summed grayscale intensities visualized areas of the somatic surface, which displayed a high $\mathrm{GABA}_{\mathrm{A}} \mathrm{R}$ labeling density (see Figs. 4, 5D). After selecting an appropriate threshold of grayscale value, putative synaptic areas could be delineated based on local $\mathrm{GABA}_{\mathrm{A}} \mathrm{R}$ labeling density on the surface of neurons (see Fig. $4 C$ ). Finally, the areas of the delineated synapses were measured and immunogold particles labeling NMDARs were counted in the synapses (see Fig. 4D).

As described above, we used two subjective parameters in these measurements. The gradient disks extended " $200 \mathrm{~nm}$ " from the edge of the gold particles, and we selected a certain appropriate "threshold of grayscale value" to delineate putative synaptic areas. These two parameters depended on the intensity of the labeling with the $\mathrm{GABA}_{\mathrm{A}} \mathrm{R}$ antibody and needed to be set only once in the beginning of the measurement, so that the delineated areas seemed to very closely approximate putative synaptic areas. However, once these parameters were set, they were used on all samples in all experiments, independent from the position of NMDAR immunogold labeling. Other combinations of parameters were also tested, which provided synaptic areas of different shape and size, but those measurements have led to identical conclusions, likely because NMDARs seemed to distribute evenly in these GABAergic synapses.

The main purpose of this delineation procedure was not to reproduce exactly the same synapse definition, as it was possible by observing presynaptic and postsynaptic structures in synapses cut perpendicularly to the plane of the synaptic cleft. Here, the main purpose was to find $\mathrm{GABA}_{\mathrm{A}} \mathrm{R}$-associated areas (GABAergic synapses, in the present study) and to delineate them in an unbiased fashion; therefore, this method provided an unbiased approach for testing association of NMDARs to GABAergic synapses in replica samples.

Preembedding immunogold-immunoperoxidase double labeling. For nNOS immunolabeling, the same method was used as previously de- 
scribed (Szabadits et al., 2007), but for NMDAR labeling, animals were perfused with $4 \%$ paraformaldehyde in $0.1 \mathrm{M}$ PB. For synaptic detection of NMDARs, pretreatment with pepsin was essential (Watanabe et al., 1998). Sections were incubated in $0.2 \mathrm{M} \mathrm{HCl}$ solution containing $1 \mathrm{mg} / \mathrm{ml}$ pepsin (Dako) at $37 \mathrm{C}^{\circ}$ for $10 \mathrm{~min}$. Sections were then incubated in $50 \mathrm{~mm}$ glycine (Sigma-Aldrich) and blocked in 1\% HSA in TBS. Then they were incubated only in one primary antibody or in mixtures of primary antibodies for NMDAR subunits (rabbit; $1.8 \mu \mathrm{g} / \mathrm{ml}$ GluN1; $1.8 \mu \mathrm{g} / \mathrm{ml}$ GluN2A; $1.3 \mu \mathrm{g} / \mathrm{ml}$ GluN2B) and vGluT3 (guinea pig; 1:3000; Millipore Bioscience Research Reagents; AB5421) or NMDAR subunits and parvalbumin (PV) (mouse monoclonal antibody; 1:7000; Swant) diluted in TBS containing $0.1 \%$ BSA-c (Aurion; TBS-BSA-c) for $72 \mathrm{~h}$. After repeated washes in pure TBS-BSA-c, sections were incubated in $1.4 \mathrm{~nm}$ gold-conjugated anti-rabbit antibody solution (Nanogold Fab' conjugated antibody; NanoProbes) diluted in TBS-BSA-c for $24 \mathrm{~h}$. After intensive washes in TBS-BSA-c, the sections were treated with $2 \%$ glutaraldehyde in $0.1 \mathrm{M} \mathrm{PB}$ for $15 \mathrm{~min}$ to fix the gold particles into the tissue. This was followed by incubation in silver enhancement solution (SE-EM; Aurion) for $40 \mathrm{~min}$ at room temperature. The sections were incubated with biotinylated secondary antibodies (goat anti-guinea pig; 1:200; Vector Laboratories; or donkey anti-mouse; 1:1000; Jackson ImmunoResearch Laboratories), respectively, for $24 \mathrm{~h}$, followed by incubation in avidinbiotinylated horseradish peroxidase complex (Elite ABC; 1:300; Vector Laboratories) diluted in TBS for $3 \mathrm{~h}$. The immunoperoxidase reaction was developed using DAB (3,3-diaminobenzidine) (Sigma-Aldrich) as chromogen. The sections were treated with $0.5 \%$ osmium tetroxide in 0.1 $\mathrm{M} \mathrm{PB}$ on ice and were dehydrated in ascending alcohol series and in acetonitrile and embedded in Durcupan (ACM; Fluka). During dehydration, the sections were treated with $1 \%$ uranyl acetate in $70 \%$ ethanol for $20 \mathrm{~min}$. For the electron-microscopic investigations, tissue samples were embedded into small Durcupan molds. After this, 60 -nm-thick sections were prepared using ultramicrotome (Leica EM UC6) and picked up on single-slot copper grids. The sections were examined using a Hitachi H-7100 electron microscope.

For the semiquantitative analyses of immunogold particles for NMDAR subunits, we counted gold particles within the anatomically defined GABAergic synapses and along the somatic membrane. A band of $50 \mathrm{~nm}$ was chosen along the membrane as an area representing membrane-associated receptor labeling in the digested hippocampal samples.

Analysis. When data populations in this work had a Gaussian distribution according to the Shapiro-Wilk's $W$ test, we reported parametric statistical features (mean $\pm \mathrm{SD}$ ). When the correlation between gold particles and synaptic sizes was tested, some data populations were nonGaussian; therefore, we used nonparametric statistics (Spearman's $R$ correlation). These correlations were considered significant when the $p$ level was $<0.05$.

\section{Results \\ NMDA induces cGMP production in GABAergic terminals in the CA1 subfield of acute hippocampal slices}

GABAergic terminals in the hippocampus express functional NO receptors and are able to produce cGMP (Makara et al., 2007; Szabadits et al., 2007). We prepared acute slices from dorsal hippocampi and incubated them in MACSF containing PDE-Inhs (to avoid the hydrolysis of cGMP) and L-arginine (which is the substrate of nNOS). After fixation, cGMP was visualized by immunofluorescent labeling using specific antibodies raised against cGMP bound to a carrier protein. In control slices $(n=20,10$ mice), detectable levels of neuronal cGMP immunoreactivity occurred only in a few interneuron (IN) somata and dendrites. Basket cell terminal labeling was absent in the CA1 region, whereas weak and sparse basket-like terminal staining was present in the pyramidal cell layer of CA3ab (Fig. 1A). Using double immunofluorescent labeling, we confirmed that they were indeed GABAergic terminals $(96.5 \pm 2.7 \%$ of them were GAD65 positive; $n=118$, 4 slices, 2 mice). However, $38.9 \pm 2.7 \%$ of the
GAD65-positive basket cell terminals were cGMP positive in the CA3ab (Fig. 2A) ( $n=330$, 4 slices, 2 mice). No basket-like terminal staining was detected in the dentate gyrus (DG) (Fig. $1 J$ ). Although we focused on the CA1 region, the labeling pattern was identical in the CA3c in all experiments. Some glial cells were also stained in each subfield, probably as a result of the well known expression of both NO-sensitive and -insensitive guanylyl cyclases by astrocytes (de Vente and Steinbusch, 1992).

Application of an NO donor, SNP (200 $\mu \mathrm{M}$ for $10 \mathrm{~min})$ caused a large increase in cGMP labeling in most neuronal elements. It was the strongest in basket terminals both in CA1 and CA3, but basket terminals remained unlabeled in the DG ( 5 slices, 2 mice) (Fig. $1 B, J$ ).

Then, we applied $5 \mu \mathrm{M}$ NMDA to control slices for $3 \mathrm{~min}$ (Fig. $1 C)$, which resulted in a remarkable region-specific enhancement of cGMP accumulation (27 slices, 10 mice). In addition to a strong homogenous neuropil staining in strata radiatum and oriens, a profound increase was detected in basket cell terminals of CA1. After application of $5 \mu \mathrm{M}$ NMDA for only $30 \mathrm{~s}$, terminals were still labeled in the superficial $50 \mu \mathrm{m}$ of the slices. These were indeed GABAergic terminals in stratum (str.) pyramidale (Figs. $1 \mathrm{~K}, 2 \mathrm{~A})$; $96.3 \pm 0.6 \%$ of the cGMP terminals were GAD65 positive ( $n=375,9$ slices, 3 mice), which corresponded to $57.3 \pm$ $0.6 \%$ of all GAD65-positive terminals in CA1 $(n=513,9$ slices, 3 mice). No staining was observed in the str. lacunosummoleculare. In the str. radiatum, some cGMP-labeled terminals, which appeared less intensely labeled than those around pyramidal cell somata, were also GAD65 positive. Furthermore, in the str. radiatum and oriens, most of the weaker cGMP-immunoreactive profiles did not coexpress GAD65 (likely representing either excitatory contacts or glial processes). In the CA3ab subfield, cGMP levels remained unchanged after NMDA application and were limited to GABAergic terminals ( $95.6 \pm 2.5 \%$ were GAD65 positive; $n=201$, 9 slices, 3 mice). This corresponds to $39.8 \pm 2.8 \%$ of all GAD65-positive basket cell terminals in CA3 $(n=290,4$ slices, 2 mice) (Fig. $2 A$ ).

In summary, basket cell terminals of the DG showed no immunoreactivity for cGMP either before or after NMDA treatment (Fig. $1 J$ ). The CA3ab region had some weakly cGMPlabeled GABAergic terminals in control slices, but NMDA treatment had no effect on their staining intensity or density (it changed from 38.9 to $39.8 \%$ ). However, in CA1 and CA3c, NMDA had a massive effect on cGMP labeling in GABAergic axon terminals (from the original 0 to $57.3 \%$ ). Furthermore, the positive terminals were stained much stronger than in CA3ab.

Preincubation with competitive and noncompetitive NMDAR antagonists, D-AP5 and MK-801 (50-50 $\mu \mathrm{M})$, prevented the effect of NMDA administration in CA1 but did not affect the basket terminal labeling in CA3ab, suggesting that only CA1 but not CA3ab basket synapses are regulated via NMDA-induced NO production ( $n=4$ slices, 2 mice) (Fig. $1 D$ ). To test the possible contribution of other voltage-dependent $\mathrm{Ca}^{2+}$ currents, we blocked postsynaptic L- and R-type $\mathrm{Ca}^{2+}$ channels (20 $\mu \mathrm{M}$ nifedipine plus $100 \mathrm{~nm}$ SNX-482). The effect of $5 \mu \mathrm{M}$ NMDA did not change (the results from double-immunofluorescent labeling were identical), suggesting that NMDARs are necessary and sufficient for triggering the NO-cGMP cascade ( $n=10$ slices, 2 mice) (Fig. 1E). The effect of NMDA could be completely blocked by the preincubation of slices with a NOS blocker, L-NAME (100 $\mu \mathrm{M} ; n=5$ slices, 3 mice), or the NOsGC blocker, ODQ $(20 \mu \mathrm{M} ; n=14,5$ mice) (Fig. $1 F, G)$. To test the contribution of the potentially large number of spontaneous action potentials of pyramidal cells and interneurons, these studies were 

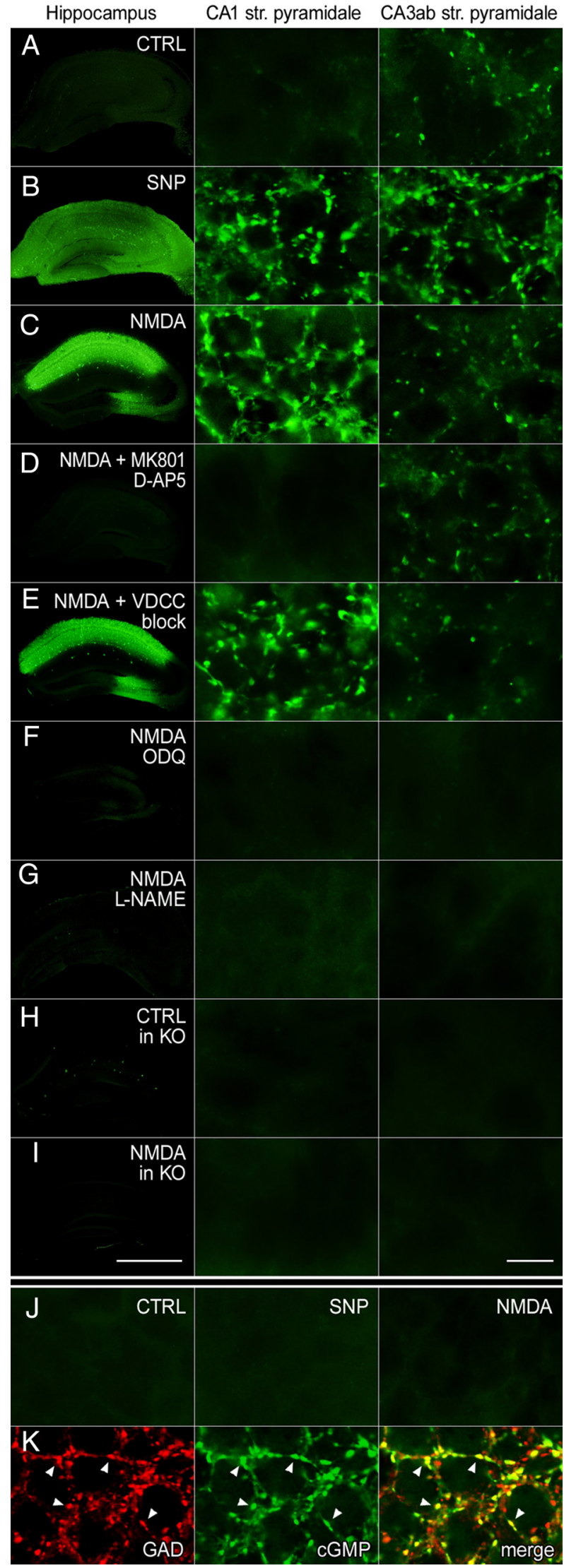

Figure 1. NMDA-induced cGMP production in acute hippocampal slices. Fluorescent images show cGMP immunolabeling in acute hippocampal slices. $A-I$, The first column shows labeling in the whole hippocampus, and the second and third columns show only the str. pyramidale of CA1 and CA3ab, respectively. Because in some areas labeling intensity is too weak to show up in repeated using $\mathrm{Mg}^{2+}$-free $\mathrm{mACSF}$, containing $1 \mu \mathrm{M}$ TTX, but the results were identical. To prove the exclusive role of nNOS, we performed experiments using nNOS ${ }^{-1-}$ mice as well (Fig. $1 \mathrm{H}, I$ ). All neuronal cGMP labeling was absent both from control $(n=8$, 4 mice) and from NMDA-treated slices $(n=9,4$ mice $)$ in all hippocampal regions. cGMP staining in blood vessels was still detectable in $\mathrm{nNOS}^{-1-}$ slices because of residual endothelial NOS activity.

These results suggest that the most likely mechanism is that local $\mathrm{Ca}^{2+}$ influx via NMDARs induces nNOS-dependent cGMP production in GABAergic terminals in the $\mathrm{CA} 1$ and $\mathrm{CA} 3 \mathrm{c}$ regions of the hippocampus. Although the present work was focused on the GABAergic synapses, it is important to note that NMDAinduced cGMP production was also detectable in the neuropil of the str. radiatum, whereas it was absent from the str. lacunosummoleculare of the CA1 region. Interestingly, the induction requirements for long-term potentiation and long-term depression in these regions are characteristically different (Takahashi and Magee, 2009; Xu et al., 2010), which may be partly explained by the above-mentioned differences.

On a technical note, interpretations of previous electrophysiological or pharmacological studies that involved applications of NMDA receptor agonists or antagonists should take into account the indirect effects on GABAergic synaptic currents as well as on network patterns mediated by the retrograde NMDA-NOcGMP pathway.

\section{GluN1, GluN2A, and GluN2B subunits are expressed in} perisomatic GABAergic synapses on CA1 pyramidal neurons The experiments above suggested that NMDARs should be very close to GABAergic synapses. Therefore, we performed quantitative postembedding immunogold labeling for GluN1, 2A, and 2B with antibodies that were confirmed to be specific in subunitspecific knock-out mice (see Materials and Methods). Pyramidal cell spines are known to express these subunits that we could also confirm (Fig. 3A-C, right column). In addition, GluN1, 2A, as well as $2 \mathrm{~B}$ subunits were also clearly detectable in the postsynaptic active zones of GABAergic synapses on pyramidal cell somata (Fig. 3A-C, left column). The average distance of immunogold labeling from the postsynaptic membrane, perpendicularly to the plane of the synapses, was $3.63 \mathrm{~nm}$ intracellularly (median; 0-12.8 interquartile range) (Fig. $2 C)(72.8 \%$ of gold particles were postsynaptic and $27.2 \%$ were in the synaptic cleft; $n=104$ gold particles), showing that NMDARs are postsynaptic in

\footnotetext{
$\leftarrow$

the low-power image, high-power images can more closely reflect differences in labeling intensity. $\boldsymbol{A}$, No immunostained varicosities were detected in control slices, except in CA3ab, where some basket terminals were labeled. $\boldsymbol{B}$, The NO donor, SNP, increased CGMP levels in all regions, but basket terminal labeling was found only in $C A 1-3$, but not in the $D G$. Note that, in CA3ab, more terminal labeling was induced by SNP than by NMDA treatment. $C$, The effect of 5 $\mu \mathrm{M} N M D A$ is region specific: strong in the $C A 1 / C A 3$ c regions, whereas no change is detectable in CA3ab. All terminals in the DG remained negative. D, The NMDAR blockers, MK-801 and D-AP5, nullified the effect of NMDA but did not change labeling in CA3ab. $E$, Blocking postsynaptic VDCCs (L- and R-type) did not change the effect of NMDA. $F$, $G$, The NO receptor blocker, ODQ, and the NOS blocker, L-NAME, prevented the NMDA-induced CGMP production. $\boldsymbol{H}, \boldsymbol{I}, \mathrm{In}$ nNOS ${ }^{-1-}$ mice, no neuronal cGMP labeling was detected, and the administration of NMDA had no effect on CGMP production. This shows that the NMDA-induced cGMP production is nNOS dependent. Scale bars: I, first column, $1 \mathrm{~mm}$; I, third column, $10 \mu \mathrm{m}$. J, CGMP production was not observed in basket cell terminals of the DG under different experimental conditions (see also str. granulosum in $\boldsymbol{A}-\boldsymbol{C})$. $\boldsymbol{K}$, Double labeling in str. pyramidale of (A1 after NMDA treatment showed that CGMP-positive terminals were GAD65 positive, whereas the majority of somatic GAD65-positive terminals were labeled for CGMP. The white arrowheads show examples of colocalization. Scale bar: (in $\boldsymbol{I}$, third column), $\boldsymbol{J}, \boldsymbol{K}, 10 \mu \mathrm{m}$.
} 
GABAergic synapses as well. No labeling was detected presynaptically.

Next, using this quantitatively reliable method, we estimated the NMDAR labeling density in excitatory and perisomatic inhibitory synapses. We measured the labeling density of the GluN1 subunits, for it is present in all NMDARs uniformly. Random samples were collected from perisomatic GABAergic ( $n=54$ synapses from 2 mice), and dendritic spine synapses (from the str. radiatum; $n=98,2$ mice). In GABAergic synapses, the density of NMDAR labeling was $9.73 \pm 1.34$ times weaker than in spine synapses (GABAergic, $2.55 \pm 0.13$; spine, $24.84 \pm 4.71$ gold/ $\mu \mathrm{m}$ ) (Fig. 2 B). Since somatic GABAergic synapses are $\sim 1.8$ times larger than spine synapses (Racca et al., 2000; Nyíri et al., 2001), the former have $\sim 5.4 \pm 0.75$ times less NMDARs than the latter. Some NMDARs were also found extrasynaptically on pyramidal cell bodies $(0.198 \pm$ 0.03 gold $/ \mu \mathrm{m}$ ) (Fig. $2 B$ ).

To directly prove that different NMDAR subunits coexist in the very same synapses, we localized different subunits in consecutive sections of the same synapse (for details, see Materials and Methods). We found that GluN1-2A, GluN1-2B, and GluN2A-2B subunits frequently colocalized (Fig. 3D,E). Moreover, the three subunits could also be detected in the very same synapse (Fig. $3 E$ ). These results show that the same GABAergic synapse may use both GluN2A and GluN2B subunit-containing NMDARs, postsynaptically.

The majority of somatic GABAergic synapses of CA1 pyramidal cells possess all three types of NMDAR subunits: quantitative data

To examine the proportion of GABAergic synapses containing NMDARs, a large number of reconstructed synapses are needed; therefore, we performed SDS-digested freezefracture replica immunolabeling. Complete synaptic active zones are revealed on the surface of pyramidal cell bodies, when the lipid bilayer of the plasma membrane fractures into two pieces: the exoplasmic (E)face underlain by extracellular surface and the protoplasmic (P)-face underlain by cytoplasmic surface. An antibody against the $\mathrm{C}$ terminus of the $\mathrm{GABA}_{\mathrm{A}} \mathrm{R} \beta 3$ subunit labeled dense clusters of IMPs on the P-face (Kasugai et al., 2010). Putative GABAergic synapses on the soma membrane, having a high local density of $\mathrm{GABA}_{\mathrm{A}} \mathrm{R}$ subunit immunogold labeling, were identified by an unbiased delineation protocol (see Materials and Methods) (Fig. 4). Then, using double immunogold labeling for $\mathrm{GABA}_{\mathrm{A}} \mathrm{R}$ and NMDAR subunits, we estimated the minimum proportion of GABAergic synapses that express
A $\%$ of colocalization of GAD-cGMP labeling in basket terminals, in control and after NMDA treatment
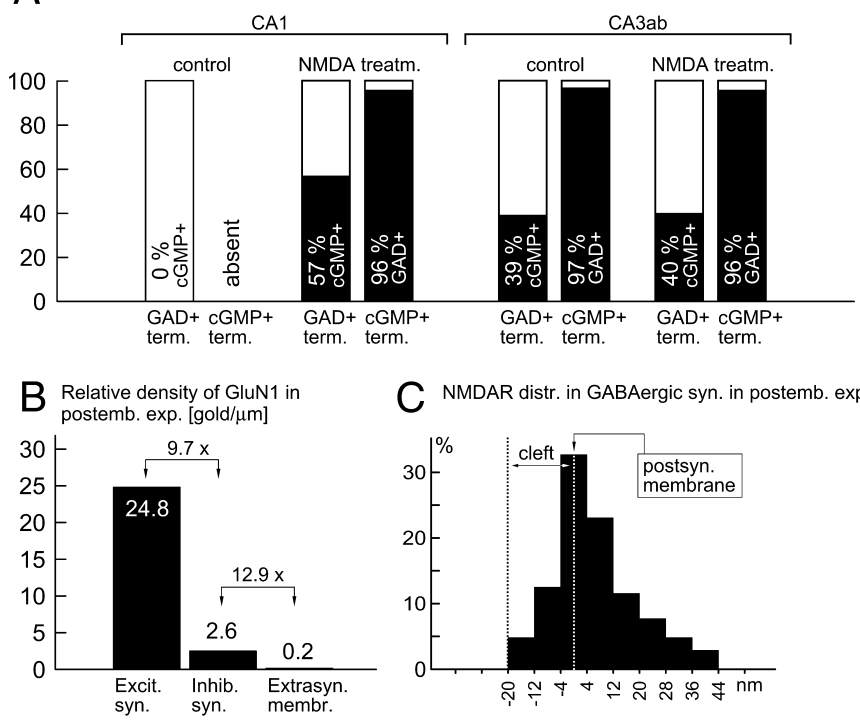

C NMDAR distr. in GABAergic syn. in postemb. exp.

Density of GluN1 lab. on replica
[gold/ $\left.\mu \mathrm{m}^{2}\right]$
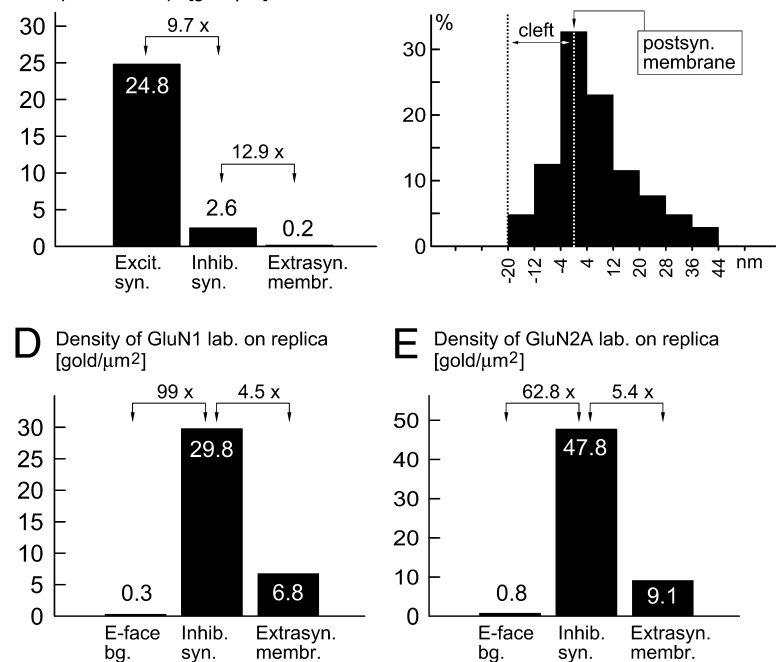

E Density of GluN2A lab. on replica E [gold $/ \mu \mathrm{m}^{2}$ ]

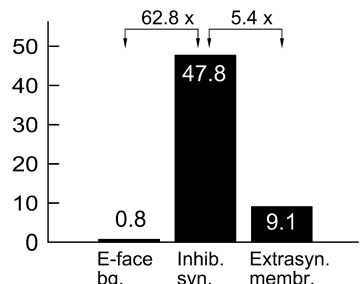

- Density of GluN2B lab. on replica [gold $/ \mu \mathrm{m}^{2}$ ]

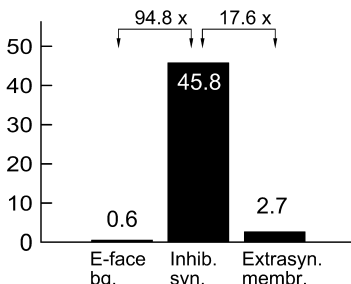

$G \%$ of NMDAR+ somatic syn. (replica labeling)

$\begin{array}{lll}\text { E-face } & \text { Inhib. } & \text { Extrasyn } \\ \text { bg. } & \text { syn. } & \text { membr. }\end{array}$

bg.
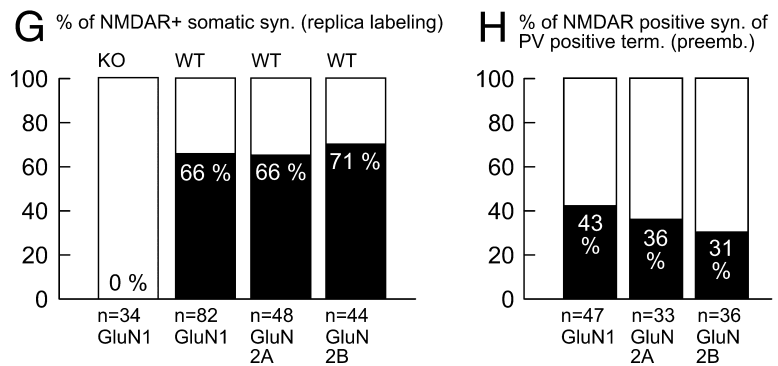

\% of NMDAR positive syn. of
vGlut3 positive term. (preemb.)

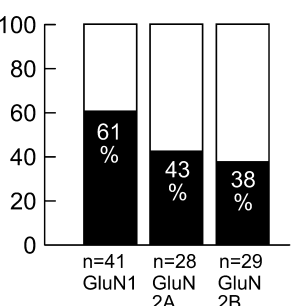

Figure 2. Analysis of the distribution of NMDAR subunits and colocalizations in basket cell terminals. $A$, Control and NMDAinduced CGMP labeling in CA1 and CA3ab basket terminals tested for GAD65 immunoreactivity. In the CA1 area, terminals were negative for CGMP in controls, whereas the majority of them became strongly positive after NMDA treatment $[n=513$ GAD + terminals (term.), $n=375 \mathrm{CGMP}+$ term., 3 mice]. In the CA3ab area, some of the terminals were weakly positive for CGMP ( $n=$ $330 \mathrm{GAD}+$ term., $n=118 \mathrm{cGMP}+$ term., 2 mice), whereas the labeling did not change after NMDA treatment ( $n=290 \mathrm{GAD}+$ term., $n=201$ cGMP + term., 3 mice). $\boldsymbol{B}$, Measurements from postembedding immunogold experiments show that the density of NMDARs (GluN1 subunits) are highly enriched in inhibitory GABAergic synapses (12.9 times higher), compared with the somatic extrasynaptic membrane. Labeling density is even higher in excitatory synapses (9.7 times that of GABAergic synapses). C, The distribution of NMDAR labeling relative to the postsynaptic membrane of GABAergic synapses showed that NMDARs are associated to the postsynaptic membrane. We found no evidence for presynaptic NMDARs. $D-F$, Immunogold density for GluN1, GluN2A, and GluN2B subunits, measured on freeze-fracture replica of pyramidal cell somatic membranes. For all subunits, background (measured on the E-face) was negligible, whereas cytoplasmic P-face labeling was enriched in GABAergic synapses (Inhib. syn.), compared with labeling on adjacent somatic membranes (Extrasyn. membr.). G, NMDAR subunit labeling is enriched in the majority of the fully reconstructed somatic GABAergic synapses on freeze-fracture replica. In the pyramidal cell-specific GluN1 knock-out mice, synaptic GluN1 labeling was absent. $\boldsymbol{H}, \boldsymbol{I}$, Percentages of direct localization of NMDAR subunits in serially reconstructed PV- and vGluT3-positive synapses in immunogold-immunoperoxidase experiments. Note that immunoperoxidase staining for the axon terminal markers decreases the sensitivity of NMDAR labeling. preemb., Pre-embedding; lab., labeling.

NMDAR subunits. All NMDAR subunit antibodies labeled the spines of pyramidal cells intensively (Fig. $5 A-C$, insets) but were also associated with $\mathrm{GABA}_{\mathrm{A}} \mathrm{R}$-containing somatic synapses (Fig. $5 A-D)$. The background labeling was measured on somatic E-faces, and it was found negligible $\left(0.31 \pm 0.08 \mathrm{gold} / \mu \mathrm{m}^{2}\right.$ for GluN1, $0.79 \pm 0.16 \mathrm{gold} / \mu \mathrm{m}^{2}$ for GluN2A, and $0.55 \pm 0.18$ 


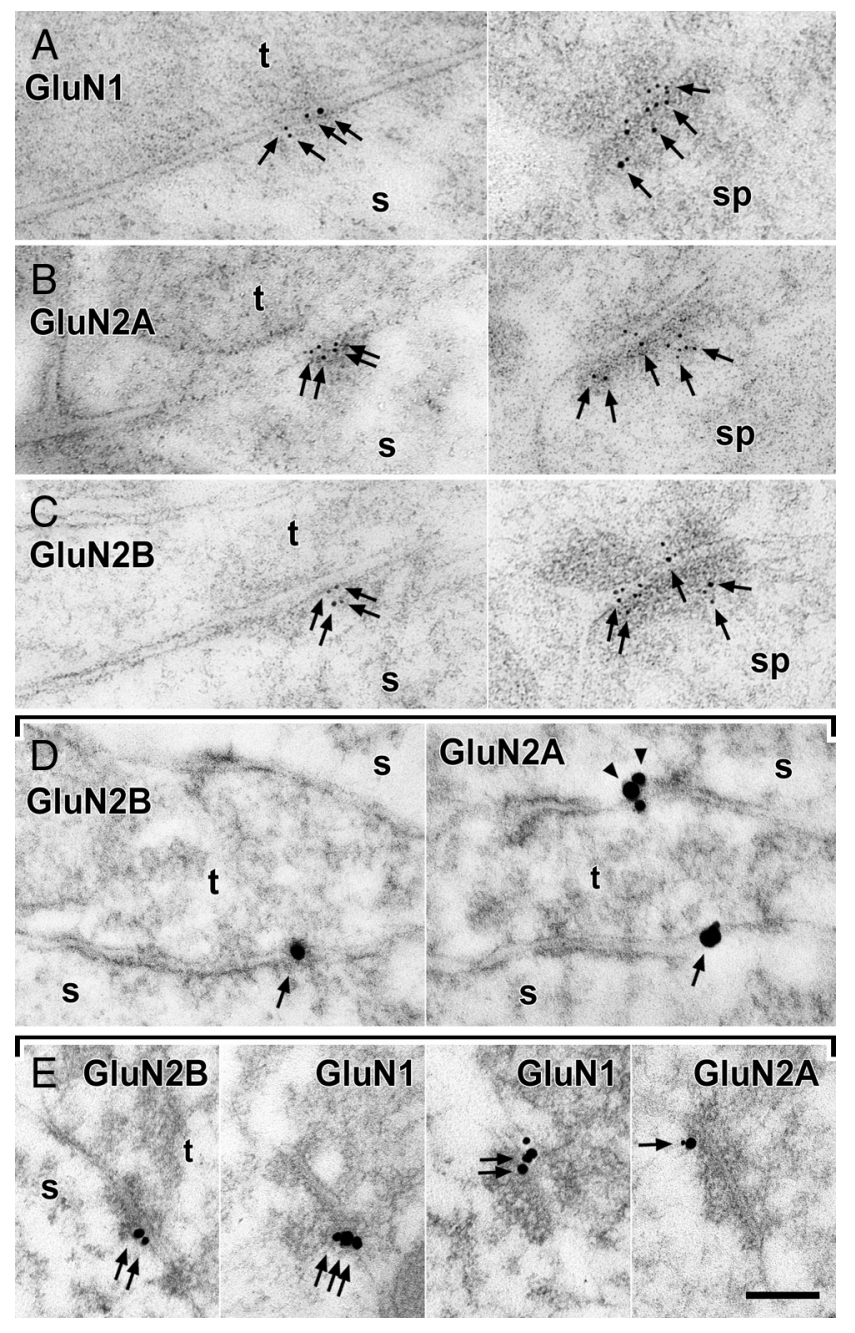

Figure 3. NMDAR subunits expressed in the active zone of somatic GABAergic synapses of CA1 pyramidal cells. Electron micrographs show postembedding immunogold labeling for NMDAR subunits (black particles). $\boldsymbol{A}-\boldsymbol{C}$, GluN1, GluN2A, and GluN2B subunits are enriched in the postsynaptic active zones of GABAergic (left) and glutamatergic synapses (right) with large quantitative differences. $\boldsymbol{D}$, Serial sections of the same synapses, tested for GluN2B and 2A (silver enhanced gold particles). The synapse in the lower half is labeled for both subunits (arrows), and the other synapse was only positive for GluN2A (arrowheads). E, Serial sections of the very same synapse show immunogold labeling for GluN2B, GluN1, as well as GluN2A subunits (arrows). t, Terminal; s, soma; sp, spine head. Scale bar, $100 \mathrm{~nm}$.

gold $/ \mu \mathrm{m}^{2}$ for GluN2B subunits). However, the density of NMDAR labeling in $\mathrm{GABA}_{\mathrm{A}} \mathrm{R}$ clustering areas (putative GABAergic synapses) was as high as $29.80 \pm 6.85 \mathrm{gold} / \mu \mathrm{m}^{2}(n=82$ synapses, 3 mice) for GluN1, $47.77 \pm 6.77 \mathrm{gold} / \mu \mathrm{m}^{2}(n=48$ synapses, 2 mice) for GluN2A, and $45.83 \pm 11.58 \mathrm{gold} / \mu \mathrm{m}^{2}(n=$ 44 synapses, 2 mice) for GluN2B. Thus, synaptic NMDAR density was $99.06,62.78$, and 94.79 times higher than the background for GluN1, 2A, and 2B antibodies, respectively (Fig. 2D-F). Accordingly, we found that $66.2 \pm 6.8 \%(n=82), 65.5 \pm 11.1 \%(n=$ $48)$, and $70.5 \pm 9.6 \%(n=44)$ of the GABAergic synapses were GluN1, 2A, and 2B positive, respectively (Fig. $2 G$ ), and in each of these synapses, the subunit labeling density was at least 30 times higher than background. The average number of gold particles for NMDAR subunits was $3.02 \pm 0.51,5.21 \pm 0.95$, and $4.41 \pm$ 0.54 gold/synapse for GluN1, 2A, and 2B subunits in NMDARpositive synapses, respectively (Fig. 5). These measurements may slightly underestimate synaptic NMDAR density compared with other membranes, because the higher density of $\mathrm{GABA}_{\mathrm{A}} \mathrm{R}$ label- ing may hamper the access of NMDAR-associated immunogold particles to synapses (see Materials and Methods).

The number of gold particles and synaptic areas showed a significant positive correlation for each subunit (Spearman's $R$ correlation; $r=0.3652, p=0.00074$ for GluN1; $r=0.5002, p=$ 0.00029 for GluN2A; $r=0.4018, p=0.0069$ for GluN2B); that is, the larger the synapse was, the more subunits were detected in it. The density of labeling did not change with the synaptic area (Spearman's $R$ correlation; $r=-0.0031, p=0.9781$ for GluN1; $r=0.1357, p=0.3576$ for GluN2A; $r=-0.2923, p=0.0542$ for GluN2B). We could not detect any synaptic gold particles for GluN1 on pyramidal cells of pyramidal cell-restricted GluN1 knock-out mice (Fig. $2 G$ ) ( $n=34,2$ mice). However, glutamatergic synapses on the dendritic shafts of INs were densely labeled in these mice (data not shown), indicating that the lack of labeling was not attributable to technical reasons in the knock-out mice.

Because electrophysiological experiments have already suggested that NMDARs may be expressed extrasynaptically (see Discussion), we also investigated the labeling of these membranes on the soma. The extrasynaptic NMDAR density was $6.76 \pm 1.72$, $9.10 \pm 1.51$, and $2.65 \pm 0.66 \mathrm{gold} / \mu \mathrm{m}^{2}$ for GluN1, $2 \mathrm{~A}$, and $2 \mathrm{~B}$ subunits, respectively. This was $4.49,5.41$, and 17.62 times lower than synaptic labeling, but still 22.05, 12.02, and 5.49 times higher than background for GluN1, 2A, and 2B subunits, respectively (Fig. 2D-F). These extrasynaptic NMDARs may be mobile receptors (Tovar and Westbrook, 2002) that may later be targeted to GABAergic synapses, or they may be associated with lipid-raft proteins to promote NMDAR internalization (Swanwick et al., 2009).

Together, at least approximately two-thirds of the somatic GABAergic synapses of CA1 pyramidal cells possess NMDAR subunits in the adult hippocampus.

\section{NMDARs are present postsynaptically in synapses formed by both basket cell types}

To identify the source of NMDAR-positive GABAergic synapses and to further confirm that NMDARs are exclusively postsynaptic, we performed preembedding immunogold labeling experiments for GluN1, 2A, and 2B subunits in the CA1 area. All NMDAR subunit labelings were postsynaptic in somatic GABAergic synapses (Fig. 6). GABAergic terminals were not labeled. The linear density of gold particles for GluN1 labeling in somatic GABAergic synapses was 0.520 gold $/ \mu \mathrm{m}$, whereas extrasynaptic labeling was much lower $(0.058$ gold $/ \mu \mathrm{m})$. This finding further confirms - now using the preembedding technique - the specific association of NMDARs with GABAergic synapses.

Then, we performed double immunogold-immunoperoxidase experiments for NMDAR-PV and NMDAR-vGluT3. The latter is known to be expressed only in cholecystokinin (CCK)containing basket cells in the hippocampus (Somogyi et al., 2004) and labels $\sim 90 \%$ of the CCK-positive basket terminals in the CA1 area (our unpublished observation). There is no overlap between the CCK- and the PV-containing subsets of interneurons in the hippocampus. First, we serially reconstructed synapses of PVand vGluT3-containing terminals. We found that, in the case of the synapses established by PV-positive terminals, $42.6 \%(n=47$ synapses from 2 mice) were labeled for GluN1, 36.4\% ( $n=33,2$ mice) for GluN2A, and 30.6\% $(n=36,2$ mice $)$ were labeled for GluN2B (Figs. $6 D, H, J, 2 H$ ). In the case of the synapses of vGluT3-positive terminals, $61.0 \%(n=41,2$ mice $)$ were positive for GluN1, 42.9\% ( $n=28,2$ mice $)$ for GluN2A, and 37.9\% $(n=$ 29, 2 mice) for GluN2B (Figs. $6 F, I, K, 2 I$ ). Although we focused on somatic synapses in this study, some dendritic inhibitory syn- 
apses were also found to be positive for NMDAR subunits (data not shown).

In our previous work, we demonstrated that nNOS is present in somatic GABAergic synapses established by PV- and CCKpositive terminals (Szabadits et al., 2007) (Fig. 6E). Using colocalization experiments, here we demonstrate directly that nNOS is also present in synapses established by vGluT3-positive terminals (Fig. 6G). Because the antibodies for nNOS and NMDARs were both raised in rabbits, there is no reliable method to directly colocalize these antibodies. Nevertheless, the fact that nNOS and NMDARs were found in basket cell synapses (in a very similar proportion) (see below) also strongly suggests that they are colocalized in the postsynaptic compartment of somatic GABAergic synapses.

\section{Discussion}

In a previous study (Szabadits et al., 2007), we provided evidence for the presence of the retrograde nNOS-cGMP signaling pathway in GABAergic synapses innervating hippocampal CA1 pyramidal cells. However, the source of a $\mathrm{Ca}^{2+}$ transient in the postsynaptic active zone of GABAergic synapses that is sufficiently large to activate nNOS was unknown. Here, we found that (1) NMDA administration markedly increased cGMP levels in GABAergic basket cell terminals in an NMDAR-, nNOS-, and NOsGC-dependent manner, specifically in the CA1 and CA3c regions, whereas cGMP accumulation was NMDA-independent in the CA3ab; (2) NMDAR subunits GluN1, GluN2A, and GluN2B were enriched in GABAergic synapses, and they were exclusively postsynaptic; (3) at least twothirds of the somatic GABAergic synapses contained NMDAR - all three investigated subunits - at a density that was $\sim 10$ times lower than in glutamatergic synapses; (4) both PV- and CCK/vGluT3expressing basket cell terminals established synapses containing NMDARs. These data provide evidence that local activation of NMDARs expressed in GABAergic synapses in the CA1 subfield can lead to the activation of the postsynaptic nNOS. Consequently, the NMDAR-nNOS-NO-NOsGC-cGMP pathway could be a potent activity-dependent regulator of the efficacy of GABAergic synaptic transmission in the hippocampus.

\section{NMDA-induced NO signaling in hippocampal GABAergic synapses}

NMDARs and $\mathrm{Ca}^{2+}$-dependent nNOS are anchored together in glutamatergic synapses, which ensures that nNOS can be triggered in an activity-dependent manner. nNOS is also expressed in GABAergic synapses on pyramidal cell somata and can modulate synaptic transmission (Makara et al., 2007; Szabadits et al., 2007). Here, we examined whether NMDARs could be responsible for the activation of nNOS in GABAergic synapses and for the subsequent production of cGMP in GABAergic terminals. Using radioimmunoassay from hippocampal slices, other investigators have shown that, whereas NMDA $(300 \mu \mathrm{M})$ can induce a large cGMP increase in CA1 of wild-type mice, no increase was detected in NOsGC $\alpha 1^{-/-}$mice (Taqatqeh et al., 2009). Since the NOsGC $\alpha 1$ subunit-containing NO receptors are expressed only in GABAergic interneurons in this area (Szabadits et al., 2007), those results clearly suggested that NMDA-induced cGMP accumulation occurred primarily in GABAergic interneurons. Indeed, we found that administration of only $5 \mu \mathrm{M}$ NMDA to acute hippocampal slices induced a massive accumulation of cGMP in basket cell axon terminals. This was unlikely to be attributable to NMDAR-mediated effects directly on interneurons, because it remained unchanged in the presence of TTX-mediated blockade of neuronal activity. Furthermore, it was suggested that $<10 \mu \mathrm{M}$ NMDA is unlikely to induce NO production by nNOS-positive interneurons and, even if NO production is induced with $100 \mu \mathrm{M}$ NMDA, TTX was able to block its effect (Lovick et al., 1999) (for review, see Garthwaite, 2008). This suggests that it is highly improbable that $5 \mu \mathrm{M}$ NMDA could have any effect on NO production of interneurons in the presence of TTX, in our experiments. $\mathrm{Ca}^{2+}$ channel blockade did not change the NMDA-mediated effects in our study, suggesting that $\mathrm{Ca}^{2+}$ influx via NMDARs was sufficient. In addition, physiological experiments suggest that the NO concentration is only 1-2 nM around the site of production and decreases rapidly around the synapse because of the high consumption rate of the tissue (Hall and Garthwaite, 2009). Thus, it is unlikely that NO produced farther away than a few hundred nanometers could affect the local signal in the axon terminals. The NMDA-induced cGMP accumulation was completely blocked by inhibitors of NMDAR, nNOS, or NOsGC, and was undetectable in $\mathrm{nNOS}^{-1-}$ mice. These results suggest that NMDARs directly associated with somatic GABAergic synapses were responsible for activating the nNOS-NO-NOsGC-cGMP cascade.

Although we focused on the CA1 area in this study, our results demonstrate that the NO-dependent modulation of basket cell 


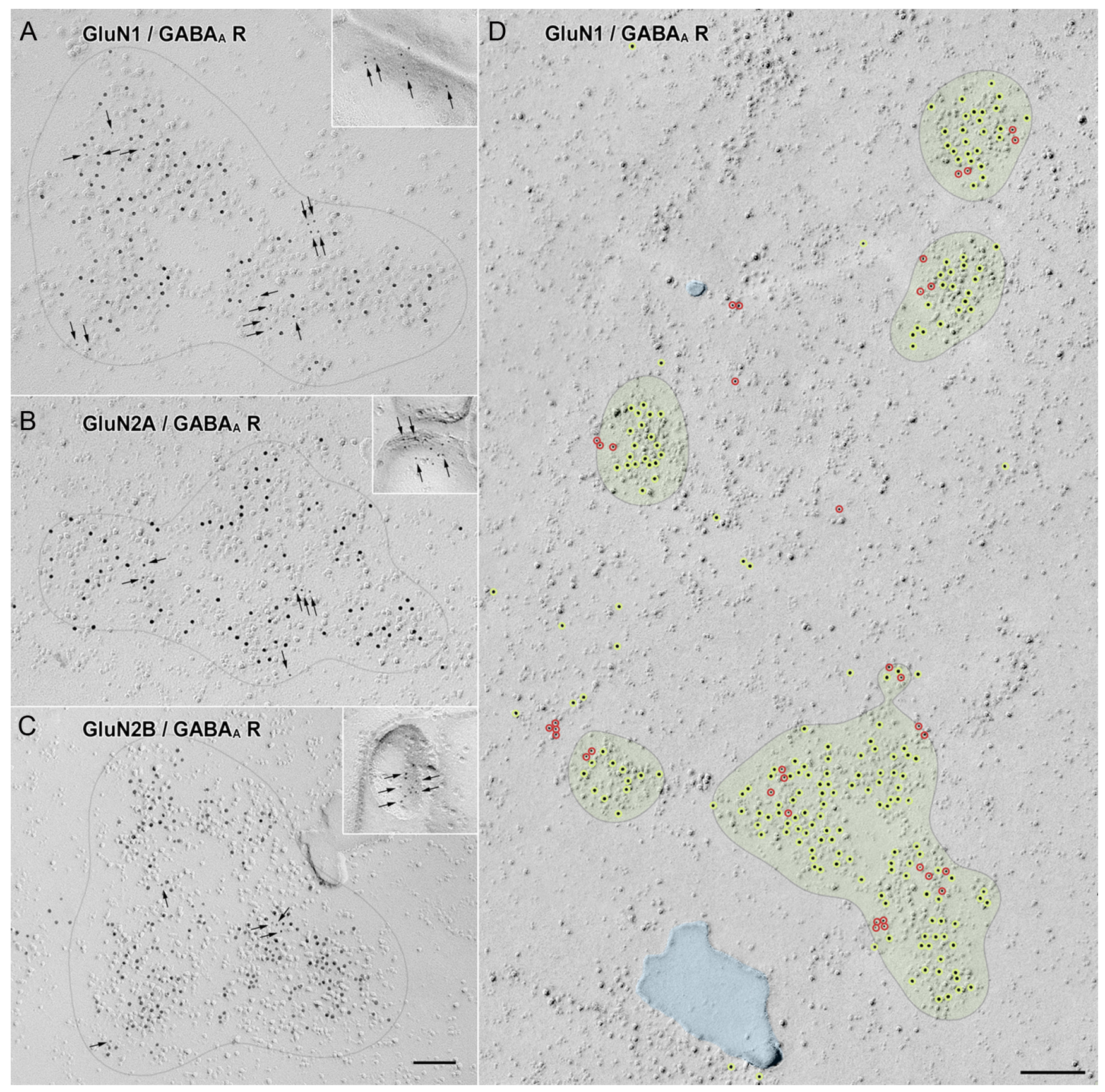

Figure 5. NMDARs colocalize with postsynaptic $G A B A_{A} R s$ on freeze-fracture replica. Electron micrographs of replica immunogold labeling show the postsynaptic side of $G A B A e r g i c$ synapses (delineated with gray lines) on CA1 pyramidal cell somata. $A-C$, Double immunogold labeling for $G A B A_{A} R B 3$ subunit ( $10 \mathrm{~nm}$ gold) and NMDAR subunits ( $5 \mathrm{~nm}$ gold; arrows) revealed a strong association of GluN1 $(\boldsymbol{A})$, GluN2A $(\boldsymbol{B})$, and GluN2B $(\boldsymbol{C})$ subunits to GABAergic synapses. The insets show labeling of presumed pyramidal cell spines for the NMDAR subunit. Scale bar, $100 \mathrm{~nm}$. $\boldsymbol{D}$, Electron micrograph demonstrates the close association of NMDARs and synaptic $G A B A_{A} R$. Five synaptic areas are shown. IMPs are scattered all over the cytoplasmic $P$-face of the somatic membrane. Two pieces of extracellular $E$-face membrane can be seen on the surface of the replica (blue areas). Immunogold labeling for $G A B A_{A} R \beta 3$ subunits (marked with green rings) are enriched over clusters of IMPs. Based on the local density of $G A B A_{A} R$ labeling, synaptic areas are delineated by the unbiased rules (pale green areas with gray edges). Then, immunogold labeling for GluN1 subunits was localized as well (marked with red rings). Finally, the density of immunogold labeling for GluN1 subunits was calculated in synapses and extrasynaptically. Scale bar, $200 \mathrm{~nm}$.

synapses operates differently in distinct regions of the hippocampus. The NO donor can increase the cGMP signal in basket cell terminals of all areas of the Ammon's horn, but not in the DG, suggesting that NO-mediated modulation of basket cell synapses is possible only in the CA1-3 subfields. However, there were striking differences between subfields even within the Ammon's horn. Basket terminals of the CA1 and CA3c had no basal nNOScGMP activity, but could be massively activated by NMDA, whereas basket terminals of the CA3ab region had some basal activity, but that could not be activated any further by NMDA application. Differences in NMDAR binding alone cannot explain these regional differences, because binding in $\mathrm{CA} 3 \mathrm{c}$ is not different from other CA3 regions, and the NMDAR binding is high in the DG as well (Monaghan and Cotman, 1985). These regional differences were detected in TTX-containing $\mathrm{Mg}^{2+}$-free solution as well, showing that it is unlikely to be attributable to regional differences in the voltage sensitivity of the NMDARs. In a previous study, high spatial resolution microinjections of 
NMDA were made close to hippocampal principal cell bodies, and the nearby NO concentration was detected directly by a microsensor (Ledo et al., 2004). NO concentrations measured in those experiments correlated well with the region-specific NMDA-induced cGMP production found in the present study. However, our results suggest that most of the measured differences are attributable to the massive activation of the nNOS-cGMP cascade at local perisomatic GABAergic terminals, rather than at glutamatergic terminals, which are tens of micrometers away in the str. radiatum.

\section{NMDAR and nNOS colocalize in GABAergic synapses}

We reported previously (Szabadits et al., 2007 ) that $\sim 75 \%$ of somatic GABAergic synapses are nNOS positive postsynaptically, whereas $79 \%$ of their terminals contain NO receptors (NOsGC $\alpha 1 \beta 1$ ). Here, we show that $\sim 57 \%$ of these GABAergic terminals produce cGMP after NMDA administration, and at least $\sim 66 \%$ of these synapses express NMDAR subunits GluN1, $2 \mathrm{~A}$, and $2 \mathrm{~B}$, postsynaptically. These subunits did not distribute differentially in the synapses of distinct types of basket cell, which suggests that the NMDARnNOS-NO-NOsGC-cGMP pathway exists in most somatic GABAergic synapses.

The $\mathrm{Ca}^{2+}$-dependent nNOS requires $\sim 0.5-1 \mu \mathrm{M} \mathrm{Ca}^{2+}$ concentration to produce NO (Lee and Stull, 1998). In glutamatergic synapses, such a large $\mathrm{Ca}^{2+}$ increase originates from the functionally coupled NMDARs (Brenman and Bredt, 1997). The postsynaptic association of the NMDAR and nNOS molecules can secure an activity-dependent and spatially restricted NO source in synapses, which greatly enhances information-processing capacity and spatial selectivity. This may be particularly important in the synapses formed by GABAergic interneurons that play fundamental roles in the control of population discharge patterns in the hippocampus (Freund, 2003). Although here we estimated that approximately five times less NMDARs were present in GABAergic than in glutamatergic synapses, kinetic studies suggested that it was more than sufficient to trigger presynaptic cGMP accumulation because of the highly efficient detection and amplification of the NO signal (Garthwaite, 2008).

Both nNOS and NMDARs are anchored to PDZ domain-containing proteins in the postsynaptic density of glutamatergic synapses. However, a PDZ domain-containing anchoring protein,
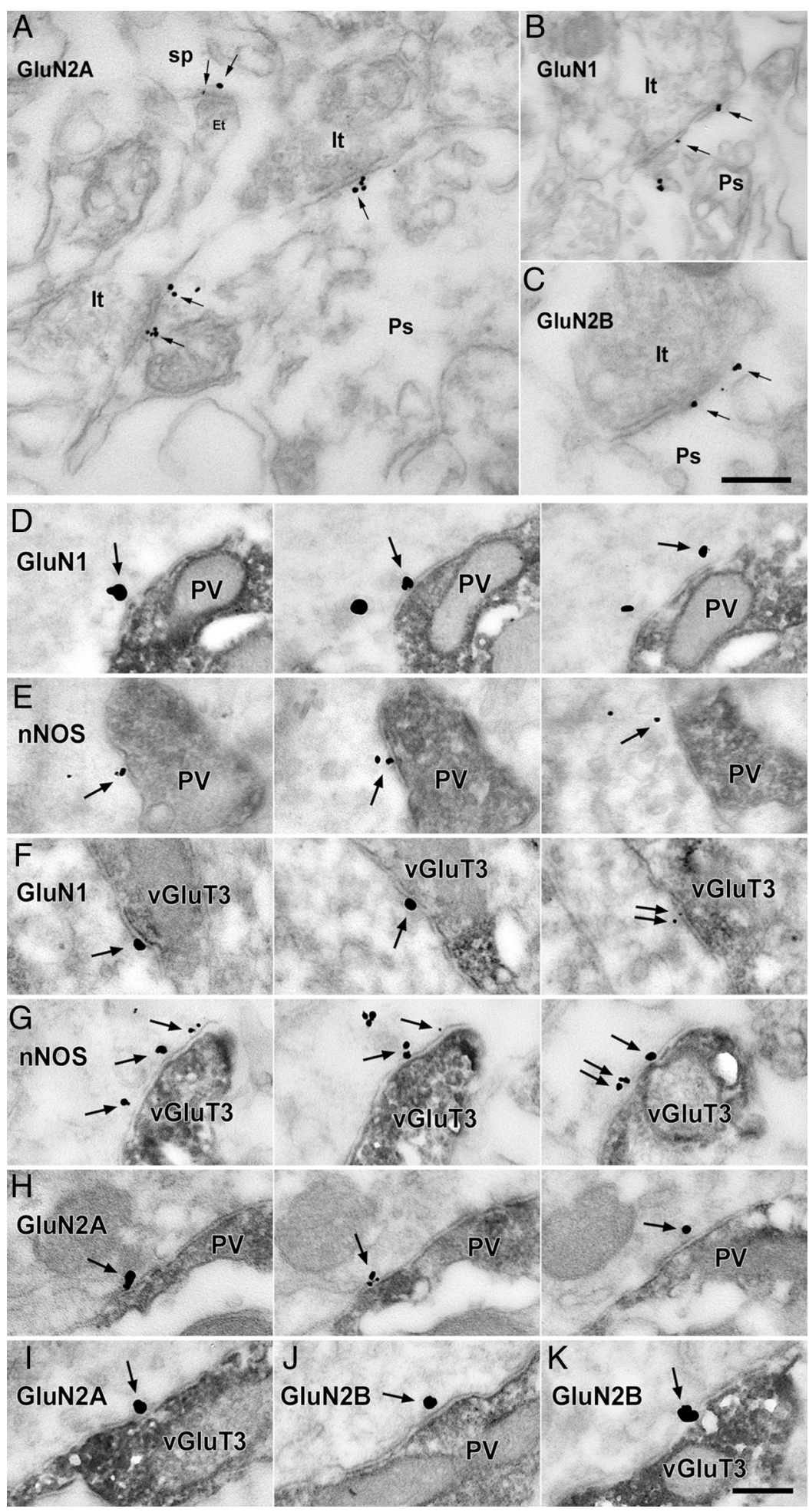

Figure 6. NMDAR and nNOS colocalize in GABAergic synapses of basket cell terminals. A-C, Electron micrographs demonstrate NMDAR subunit labeling in the postsynaptic active zone of somatic GABAergic synapses using preembedding immunogold single staining for GluN1, GluN2A, and GluN2B (arrows). No presynaptic labeling was found. In $A$, a pyramidal cell spine (sp) synapse was also labeled. Et, Excitatory terminal; It, inhibitory terminal; Ps, pyramidal cell soma. Scale bar: (in $\boldsymbol{C}) \boldsymbol{A}-\boldsymbol{C}, 200 \mathrm{~nm}$. D-K, Preembedding immunogold-immunoperoxidase colocalizations in synapses established by PVand vGluT3/CCK-positive basket cell terminals. Serial $(\boldsymbol{D}, \boldsymbol{F}, \boldsymbol{H})$ and single $(\boldsymbol{I}-\boldsymbol{K})$ sections of somatic GABAergic synapses express GluN1, 2A, and 2B (arrows; gold particles) in synapses of both PV- and vGluT3-immunoreactive terminals (dark precipitation). $\boldsymbol{E}$, Serial sections show that PV-positive synapses also express nNOS postsynaptically, as reported previously (Szabadits et al., 2007). G, The direct colocalization of nNOS (arrows) in the synapses of vGluT3 terminals is confirmed. Scale bar: (in $\boldsymbol{K}) \boldsymbol{D}-\boldsymbol{K}, 250 \mathrm{~nm}$. 
synaptic scaffolding molecule (SSCAM) was also found in hippocampal GABAergic synapses (Sumita et al., 2007), and the interaction of SSCAM with NMDAR subunits was also demonstrated (Hirao et al., 1998). Accordingly, these proteins may be responsible for anchoring both NMDARs and nNOS in GABAergic synapses.

NMDAR-mediated currents have long been described in pyramidal cell somata, and electrophysiological data suggested that more than one-third of all NMDARs localize outside of excitatory synapses. Consistent with our results, recent findings suggest that, in addition to GluN1, these receptors consist of both GluN2A and GluN2B subunits on somata (Harris and Pettit, 2007). Here, we provided evidence that GABAergic synapses expressed all of these subunits; nevertheless, we also showed that some of them belonged to extrasynaptic NMDARs. Pyramidal cell somata do not receive glutamatergic synapses (Megías et al., 2001), which further suggests that these receptors are extrasynaptic.

\section{Possible mechanisms for activating NMDARs in GABAergic synapses}

Glutamate and aspartate are the most potent endogenous ligands of NMDARs. Hippocampal CCK-containing basket cells express the glutamate transporter vGluT3 (Somogyi et al., 2004). Interestingly, corelease of glutamate from vGluT3-positive GABAergic terminals is crucial in the auditory system (Noh et al., 2010). Surprisingly, some hippocampal GABAergic terminals may also release aspartate from vesicles (Gundersen et al., 2004), and the only known vesicular aspartate transporter has also been shown on hippocampal synaptic vesicles (Miyaji et al., 2008). Thus, aspartate and/or glutamate, released from hippocampal GABAergic terminals, may activate NMDARs within the GABAergic synapse itself. Although, in the dentate gyrus, NMDARs were also revealed in somatic asymmetric and symmetric synapses, and immunocytochemical evidence was provided for the release of aspartate from GABAergic terminals (Gundersen et al., 2004), the NO-mediated regulation seems to be different there, since we did not find cGMP signal in basket cell terminals in the dentate gyrus.

Another possible mechanism for activating these NMDARs is the release of glutamate from astrocytes. Repetitive firing of perisomatic GABAergic interneurons was shown to trigger calcium waves in neighboring astrocytes via $\mathrm{GABA}_{\mathrm{B}}$ receptor activation. As a consequence, these astrocytes released glutamate, which was shown to change IPSCs. The effect could be blocked by ionotropic glutamate receptor antagonists (Kang et al., 1998).

To efficiently trigger the NMDAR-nNOS-cGMP pathway at GABAergic synapses, the glutamate or aspartate signals should coincide with depolarization of the somatic membrane that is likely brought about by action potential firing. Dendritic or backpropagating action potentials may affect distal GABAergic synapses as well. Thus, this mechanism-also influenced by the activation state of the astrocytic network-may allow a modification of GABAergic transmission as a function of the activity of both the target pyramidal cells and afferent interneurons.

\section{References}

Abe M, Fukaya M, Yagi T, Mishina M, Watanabe M, Sakimura K (2004) NMDA receptor GluRe/NR2 subunits are essential for postsynaptic localization and protein stability of GluR $\zeta 1 / \mathrm{NR} 1$ subunit. J Neurosci 24: 7292-7304.

Akashi K, Kakizaki T, Kamiya H, Fukaya M, Yamasaki M, Abe M, Natsume R, Watanabe M, Sakimura K (2009) NMDA receptor GluN2B (GluRe2/ NR2B) subunit is crucial for channel function, postsynaptic macromolec- ular organization, and actin cytoskeleton at hippocampal CA3 synapses. J Neurosci 29:10869-10882.

Alderton WK, Cooper CE, Knowles RG (2001) Nitric oxide synthases: structure, function and inhibition. Biochem J 357:593-615.

Baude A, Nusser Z, Roberts JD, Mulvihill E, McIlhinney RA, Somogyi P (1993) The metabotropic glutamate receptor $(\mathrm{mGluR} 1 \alpha)$ is concentrated at perisynaptic membrane of neuronal subpopulations as detected by immunogold reaction. Neuron 11:771-787.

Bredt DS, Snyder SH (1990) Isolation of nitric oxide synthetase, a calmodulin-requiring enzyme. Proc Natl Acad Sci U S A 87:682-685.

Brenman JE, Bredt DS (1997) Synaptic signaling by nitric oxide. Curr Opin Neurobiol 7:374-378.

Burette A, Zabel U, Weinberg RJ, Schmidt HH, Valtschanoff JG (2002) Synaptic localization of nitric oxide synthase and soluble guanylyl cyclase in the hippocampus. J Neurosci 22:8961-8970.

Chang YC, Gottlieb DI (1988) Characterization of the proteins purified with monoclonal antibodies to glutamic acid decarboxylase. J Neurosci 8:2123-2130.

de Vente J, Steinbusch HW (1992) On the stimulation of soluble and particulate guanylate cyclase in the rat brain and the involvement of nitric oxide as studied by cGMP immunocytochemistry. Acta Histochem 92:13-38.

de Vente J, Steinbusch HW, Schipper J (1987) A new approach to immunocytochemistry of $3^{\prime}, 5^{\prime}$-cyclic guanosine monophosphate: preparation, specificity, and initial application of a new antiserum against formaldehyde-fixed $3^{\prime}, 5^{\prime}$-cyclic guanosine monophosphate. Neuroscience 22:361-373.

Domek-Łopacińska K, Strosznajder JB (2005) Cyclic GMP metabolism and its role in brain physiology. J Physiol Pharmacol 56 [Suppl 2]:15-34.

East SJ, Garthwaite J (1991) NMDA receptor activation in rat hippocampus induces cyclic GMP formation through the L-arginine-nitric oxide pathway. Neurosci Lett 123:17-19.

Edwards TM, Rickard NS (2007) New perspectives on the mechanisms through which nitric oxide may affect learning and memory processes. Neurosci Biobehav Rev 31:413-425.

Freund TF (2003) Interneuron diversity series: rhythm and mood in perisomatic inhibition. Trends Neurosci 26:489-495.

Fukaya M, Kato A, Lovett C, Tonegawa S, Watanabe M (2003) Retention of NMDA receptor NR2 subunits in the lumen of endoplasmic reticulum in targeted NR1 knockout mice. Proc Natl Acad Sci U S A 100:4855-4860.

Garthwaite J (2008) Concepts of neural nitric oxide-mediated transmission. Eur J Neurosci 27:2783-2802.

Garthwaite J, Garthwaite G, Palmer RM, Moncada S (1989) NMDA receptor activation induces nitric oxide synthesis from arginine in rat brain slices. Eur J Pharmacol 172:413-416.

Gibb AJ, Colquhoun D (1991) Glutamate activation of a single NMDA receptor-channel produces a cluster of channel openings. Proc Biol Sci 243:39-45.

Gundersen V, Holten AT, Storm-Mathisen J (2004) GABAergic synapses in hippocampus exocytose aspartate on to NMDA receptors: quantitative immunogold evidence for co-transmission. Mol Cell Neurosci 26: $156-165$.

Hall CN, Garthwaite J (2009) What is the real physiological NO concentration in vivo? Nitric Oxide 21:92-103.

Harris AZ, Pettit DL (2007) Extrasynaptic and synaptic NMDA receptors form stable and uniform pools in rat hippocampal slices. J Physiol 584:509-519.

Hirao K, Hata Y, Ide N, Takeuchi M, Irie M, Yao I, Deguchi M, Toyoda A, Sudhof TC, Takai Y (1998) A novel multiple PDZ domain-containing molecule interacting with $N$-methyl-D-aspartate receptors and neuronal cell adhesion proteins. J Biol Chem 273:21105-21110.

Ito I, Futai K, Katagiri H, Watanabe M, Sakimura K, Mishina M, Sugiyama H (1997) Synapse-selective impairment of NMDA receptor functions in mice lacking NMDA receptor epsilon 1 or epsilon 2 subunit. J Physiol 500:401-408.

Iwasato T, Datwani A, Wolf AM, Nishiyama H, Taguchi Y, Tonegawa S, Knöpfel T, Erzurumlu RS, Itohara S (2000) Cortex-restricted disruption of NMDAR1 impairs neuronal patterns in the barrel cortex. Nature 406:726-731.

Kang J, Jiang L, Goldman SA, Nedergaard M (1998) Astrocyte-mediated potentiation of inhibitory synaptic transmission. Nat Neurosci 1:683-692.

Kasugai Y, Swinny JD, Roberts JD, Dalezios Y, Fukazawa Y, Sieghart W, Shigemoto R, Somogyi P (2010) Quantitative localisation of synaptic 
and extrasynaptic $\mathrm{GABA}_{\mathrm{A}}$ receptor subunits on hippocampal pyramidal cells by freeze-fracture replica immunolabelling. Eur J Neurosci 32: $1868-1888$.

Kornau HC, Schenker LT, Kennedy MB, Seeburg PH (1995) Domain interaction between NMDA receptor subunits and the postsynaptic density protein PSD-95. Science 269:1737-1740.

Laube B, Kuhse J, Betz H (1998) Evidence for a tetrameric structure of recombinant NMDA receptors. J Neurosci 18:2954-2961.

Ledo A, Frade J, Barbosa RM, Laranjinha J (2004) Nitric oxide in brain: diffusion, targets and concentration dynamics in hippocampal subregions. Mol Aspects Med 25:75-89.

Lee SJ, Stull JT (1998) Calmodulin-dependent regulation of inducible and neuronal nitric-oxide synthase. J Biol Chem 273:27430-27437.

Lovick T, Brown L, Key B (1999) Neurovascular relationships in hippocampal slices: physiological and anatomical studies of mechanisms underlying flow-metabolism coupling in intraparenchymal microvessels. Neuroscience 92:47-60.

Makara JK, Katona I, Nyíri G, Németh B, Ledent C, Watanabe M, de Vente J, Freund TF, Hájos N (2007) Involvement of nitric oxide in depolarizationinduced suppression of inhibition in hippocampal pyramidal cells during activation of cholinergic receptors. J Neurosci 27:10211-10222.

McBain CJ, Kauer JA (2009) Presynaptic plasticity: targeted control of inhibitory networks. Curr Opin Neurobiol 19:254-262.

Megías M, Emri Z, Freund TF, Gulyás AI (2001) Total number and distribution of inhibitory and excitatory synapses on hippocampal CA1 pyramidal cells. Neuroscience 102:527-540.

Miyaji T, Echigo N, Hiasa M, Senoh S, Omote H, Moriyama Y (2008) Identification of a vesicular aspartate transporter. Proc Natl Acad Sci U S A 105:11720-11724.

Monaghan DT, Cotman CW (1985) Distribution of N-methyl-D-aspartatesensitive L- $\left[{ }^{3} \mathrm{H}\right]$ glutamate-binding sites in rat brain. J Neurosci 5:29092919.

Monyer H, Sprengel R, Schoepfer R, Herb A, Higuchi M, Lomeli H, Burnashev N, Sakmann B, Seeburg PH (1992) Heteromeric NMDA receptors: molecular and functional distinction of subtypes. Science 256:1217-1221.

Noh J, Seal RP, Garver JA, Edwards RH, Kandler K (2010) Glutamate corelease at GABA/glycinergic synapses is crucial for the refinement of an inhibitory map. Nat Neurosci 13:232-238.

Nyíri G, Freund TF, Somogyi P (2001) Input-dependent synaptic targeting of $\alpha_{2}$-subunit-containing $\mathrm{GABA}_{\mathrm{A}}$ receptors in synapses of hippocampal pyramidal cells of the rat. Eur J Neurosci 13:428-442.

Nyíri G, Stephenson FA, Freund TF, Somogyi P (2003) Large variability in synaptic $N$-methyl-D-aspartate receptor density on interneurons and a comparison with pyramidal-cell spines in the rat hippocampus. Neuroscience 119:347-363.

Prast H, Philippu A (2001) Nitric oxide as modulator of neuronal function. Prog Neurobiol 64:51-68.

Racca C, Stephenson FA, Streit P, Roberts JD, Somogyi P (2000) NMDA receptor content of synapses in stratum radiatum of the hippocampal CA1 area. J Neurosci 20:2512-2522.

Somogyi J, Baude A, Omori Y, Shimizu H, El Mestikawy S, Fukaya M, Shige- moto R, Watanabe M, Somogyi P (2004) GABAergic basket cells expressing cholecystokinin contain vesicular glutamate transporter type 3 (VGLUT3) in their synaptic terminals in hippocampus and isocortex of the rat. Eur J Neurosci 19:552-569.

Steigerwald F, Schulz TW, Schenker LT, Kennedy MB, Seeburg PH, Köhr G (2000) C-terminal truncation of NR2A subunits impairs synaptic but not extrasynaptic localization of NMDA receptors. J Neurosci 20:4573-4581.

Stuehr DJ, Santolini J, Wang ZQ, Wei CC, Adak S (2004) Update on mechanism and catalytic regulation in the NO synthases. J Biol Chem 279: 36167-36170.

Sumita K, Sato Y, Iida J, Kawata A, Hamano M, Hirabayashi S, Ohno K, Peles E, Hata Y (2007) Synaptic scaffolding molecule (S-SCAM) membraneassociated guanylate kinase with inverted organization (MAGI)-2 is associated with cell adhesion molecules at inhibitory synapses in rat hippocampal neurons. J Neurochem 100:154-166.

Swanwick CC, Shapiro ME, Yi Z, Chang K, Wenthold RJ (2009) NMDA receptors interact with flotillin-1 and -2, lipid raft-associated proteins. FEBS Lett 583:1226-1230.

Szabadits E, Cserép C, Ludányi A, Katona I, Gracia-Llanes J, Freund TF, Nyíri G (2007) Hippocampal GABAergic synapses possess the molecular machinery for retrograde nitric oxide signaling. J Neurosci 27:8101-8111.

Takahashi H, Magee JC (2009) Pathway interactions and synaptic plasticity in the dendritic tuft regions of CA1 pyramidal neurons. Neuron 62: $102-111$.

Tanaka J, Markerink-van Ittersum M, Steinbusch HW, De Vente J (1997) Nitric oxide-mediated cGMP synthesis in oligodendrocytes in the developing rat brain. Glia 19:286-297.

Taqatqeh F, Mergia E, Neitz A, Eysel UT, Koesling D, Mittmann T (2009) More than a retrograde messenger: nitric oxide needs two cGMP pathways to induce hippocampal long-term potentiation. J Neurosci 29: $9344-9350$

Tochio H, Mok YK, Zhang Q, Kan HM, Bredt DS, Zhang M (2000) Formation of nNOS/PSD-95 PDZ dimer requires a preformed beta-finger structure from the nNOS PDZ domain. J Mol Biol 303:359-370.

Tovar KR, Westbrook GL (2002) Mobile NMDA receptors at hippocampal synapses. Neuron 34:255-264.

Watanabe M, Inoue Y, Sakimura K, Mishina M (1993) Distinct distributions of five $N$-methyl-D-aspartate receptor channel subunit mRNAs in the forebrain. J Comp Neurol 338:377-390.

Watanabe M, Fukaya M, Sakimura K, Manabe T, Mishina M, Inoue Y (1998) Selective scarcity of NMDA receptor channel subunits in the stratum lucidum (mossy fibre-recipient layer) of the mouse hippocampal CA3 subfield. Eur J Neurosci 10:478-487.

Xu JY, Chen R, Zhang J, Chen C (2010) Endocannabinoids differentially modulate synaptic plasticity in rat hippocampal CA1 pyramidal neurons. PLoS One 5:e10306.

Zhang XL, Zhou ZY, Winterer J, Müller W, Stanton PK (2006) NMDAdependent, but not group I metabotropic glutamate receptor-dependent, long-term depression at Schaffer collateral-CA1 synapses is associated with long-term reduction of release from the rapidly recycling presynaptic vesicle pool. J Neurosci 26:10270-10280. 